\title{
Aromatherapy in dental medicine
}

\author{
Aromaterapia în medicina dentară
}

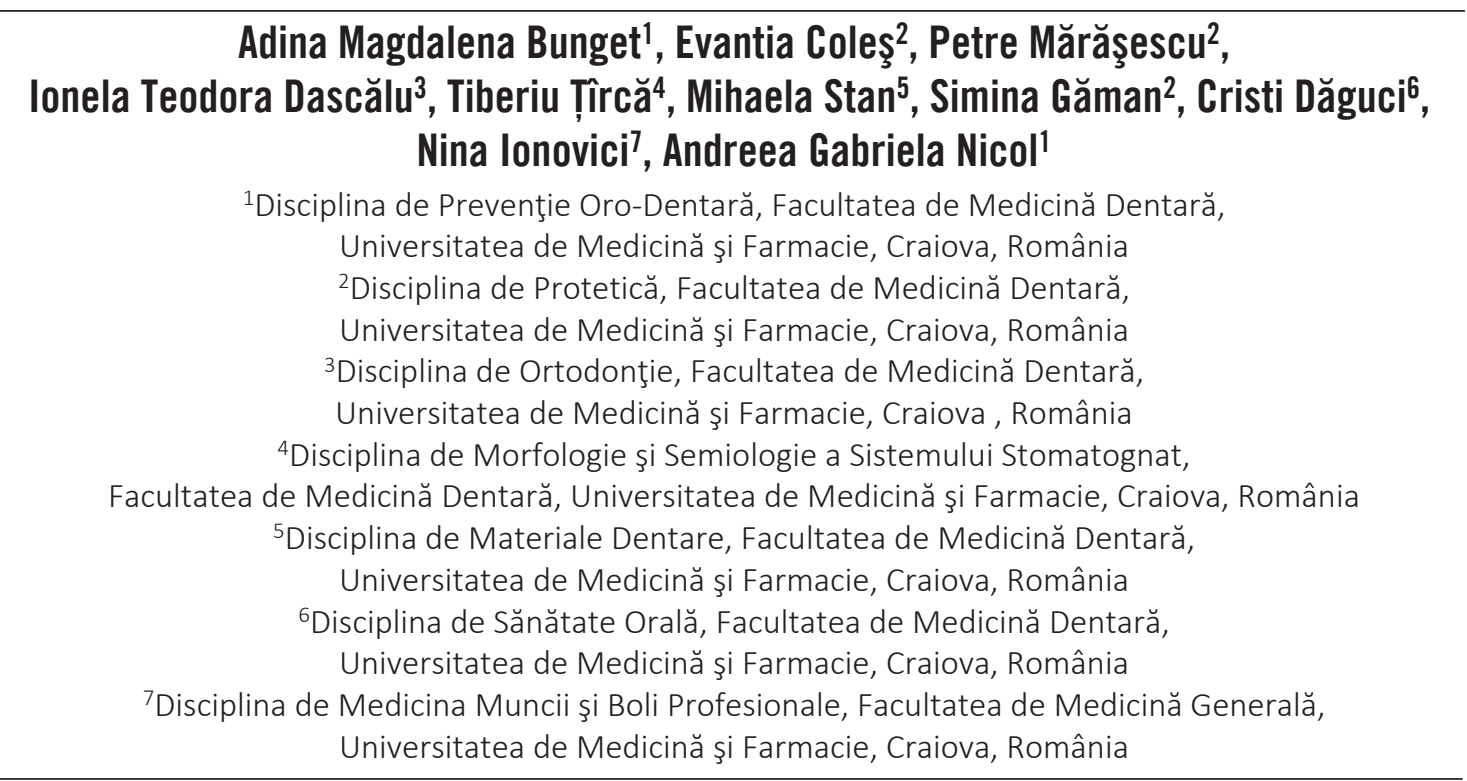

\begin{abstract}
The aim of the study was to assess presence and intensity of anxiety signs with and without aromatherapy. Aromatherapy is one of the best therapies in the world today, very appreciated for its relaxing effect on people. Many essential oils can be used for prevention and treatment of emotional distress.

20 patients were assessed by STAI questionnaire, once without using aromatherapie, and once while using aromatherapie with lavande essential oil.

The results show a reduction of anxiety when using aromatherapie.

The anxiety caused by the visit to dental office, when sitting in the waiting room, can be reduced by using aromatherapy. Proper use of essential oils shows a significantly positive improved mood.
\end{abstract}

Keywords: anxiety, aromatherapy, essential oil

\section{REZUMAT}

Scopul acestui studiu este de a evalua prezenţa şi intensitatea simptomelor de anxietate cu şi fără utilizarea aromoterapiei.

Aromaterapia este una dintre cele mai bune terapii din lume în prezent, fiind foarte apreciată pentru efectul său relaxant asupra omului. Multe uleiuri esenţiale pot fi folosite pentru prevenţia şi pentru tratamentul tul-burărilor emoţionale.

20 de pacienţi au fost evaluaţi cu ajutorul chestionarului STAI, o dată fără utilizarea aromaterapiei şi o dată în timp ce s-a utilizat aromaterapia cu ulei esenţial de lavandă.

Rezultatele arată o reducere a anxietăţii în timpul folosirii aromaterapiei.

Anxietatea provocată de vizita la cabinetul de medicină dentară, aşezat în sala de aşteptare, poate fi redusă prin utilizarea aromaterapiei. Utilizarea corectă a uleiurilor esenţiale arată o îmbunătăţire semnificativă a dispoziţiei.

Cuvinte cheie: anxietate, aromaterapie, ulei esenţial

\section{INTRODUCERE}

Anxietatea este una dintre tulburările emoţionale cele mai răspândite în lume (1).
Anxietatea este o stare afectivă ce poate fi descrisă ca un sentiment difuz de insecuritate, cu modificări însemnate la nivel cognitiv, subiectiv, comportamental şi biologic. 
Teama de dentist crează o adevărată stare de anxietate caracterizată prin nelinişte, ceea ce determină mulţi pacienţi să-şi amâne vizita la cabinetul dentar (2) sau să anuleze programarea în ultimul moment (3).

Emoţiile resimţite fizic înainte de vizita la medicul dentist, dar şi în sala de aşteptare, până la începerea şedinţei de tratament, sunt: bătăi accelerate ale inimii, senzaţia de nod în gât, senzaţia de sufocare, căldură, transpiraţii şi chiar tulburări digestive: greaţă, dureri abdominale (4).

Anxietatea de dentist este o stare dobândită fie prin empatie, din experienţele povestite ale altor persoane, fie din propriile experienţe neplăcute din trecut, un rol important avându-1 educaţia pentru sănătate orală, prima vizită la medicul dentist, vârsta şi motivul, precum şi controalele periodice pentru o evaluare clinică.

Din studiile efectuate, se evidenţiază faptul că teama şi anxietatea de dentist prezintă o incidenţă foarte crescută în toată lumea (5).

Inventarul de anxietate stare-trăsătură (StateTrait Anxiety Inventory) este un test cu două scale de autoevaluare a două concepte distincte: anxietatea ca stare (A-stare) şi anxietatea ca trăsătură (Atrăsătură) (6).

Scala constă în 20 de descrieri care indică modul în care un individ se simte în general (A-trăsătură) sau modul în care se simte la un moment dat (A-stare).

Starea anxiogenă (A-stare) reprezintă starea emoţională tranzitorie subiectivă percepută sub formă de tensiune, teamă şi activitate crescută a sistemului nervos vegetativ (7).

\section{Aromaterapia}

Utilizarea plantelor aromatice a luat fiinţă în Egiptul antic, iar medicamentele pe bază de plante au apărut de prin anii 3000 î.H, existând destule dovezi despre prezenţa parfumurilor în viaţa zilnică a egiptenilor (8).

$\mathrm{Cu}$ mult înainte de Hristos, ierburile aromatice şi masajul erau deja utilizate în China. Acum 5000 de ani, chinezii care trăiau de-a lungul Fluviului Galben foloseau frunze de pelin negru şi rădăcini de obligeană pentru igienă.

De asemenea, indienii, grecii şi romanii foloseau plante şi ierburi în diverse scopuri pentru băi aromatice, pentru masaje sau în scop medical.
Aromaterapia modernă ia naştere în 1937, apariţia acesteia putând fi atribuită chimistului francez René Maurice Gattefosse. El a fost acela care a inventat cuvântul ,,aromaterapie“", prin publicarea lucrării sale, intitulată „Aromatherapie“ (Aromaterapia). Se spune că, arzându-şi mâna într-un experiment, a scufundat-o în lichidul cel mai apropiat, care conţinea ulei de lavandă. Gattefosse folosea uleiurile esenţiale pentru vindecarea rănilor soldaţilor care luptau în Primul Război Mondial (8).

Uleiurile esenţiale din aromaterapie se obţin din flori, frunze, muguri, ramuri, rădăcini ce au fost extrase prin distilare cu abur, distilare cu apă sau prin presare la rece (Fig. 1).

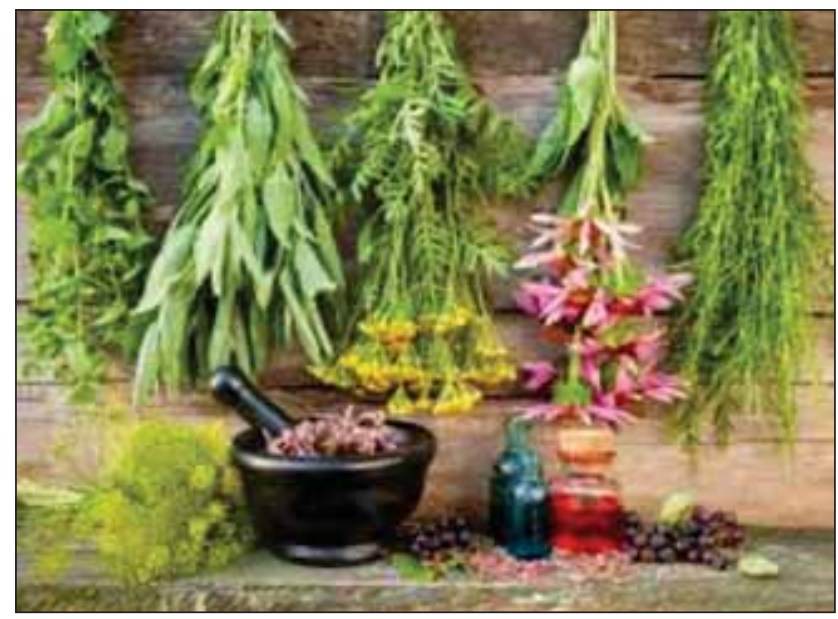

FIGURA 1. Diverse plante aromatice

http://tylerwellnesscenter.com/2016/10/essential-oils-boost-health/

Există numeroase moduri în care pot fi folosite uleiurile esenţiale:

1. Uz extern:

- Băi de plăcere sau în scop terapeutic - „Calea spre sănătate este să faci în fiecare zi o baie parfumată şi un masaj aromat", susţinea Hipocrate, părintele medicinei

- Băi hidroterapeutice şi jacuzzi

- Băi pentru mâini şi picioare

- Băi de şezut şi bideuri

- Duşuri

- Comprese

- Inhalaţii

- Gargare şi clătiri bucale

- Spray de cameră

- Vaporizatoare şi difuzoare pentru încăperi

- Masaj

- Unguente şi creme

2. Uz intern, se recomandă folosirea uleiurilor pure în cantităţi mici şi precise 
Utilizarea uleiurilor esenţiale şi a uleiurilor volatile în medicina dentară nu s-a dezvoltat foarte mult, deşi există multe efecte terpaeutice ale utilizării acestora în tratarea gingivitelor, a aftelor bucale şi a abceselor dentare.

Gargarele sunt benefice în special pentru durerile de gât, problemele respiratorii, pierderea vocii şi halitoză (respiraţie urât mirositoare).

Aromaterapia este o terapie complementară medicinei clasice, asigurând echilibrul sănătăţii fizice, mentale şi spirituale.

Uleiurile volatile au un efect dovedit în combaterea stressului, eliminarea stărilor anxioase şi inducerea unei stări de bine, calm, relaxare (9).

Particulele de ulei esenţial inhalate ajung în cavitatea nazală, unde sunt absorbite la nivelul circulaţiei generale ajungând la sistemul limbic din creier.

Sistemul limbic este o zonă care influențează emoţiile, având legătură directă cu glandele endocrine, reglând tensiunea arterială, stresul şi respiraţia, asigurând echilibrul hormonal, astfel, efectele uleiurilor esenţiale sunt imediate in realizarea echilibrului emoţional şi fiziologic.

Uleiul esenţial de lavandă este cel mai cunoscut în combaterea stressului şi inducerea unei stări de bine, cu efect de reducere a stării de anxietate (10).

Utilizarea uleiului esenţial de lavandă s-a dovedit utilă în combaterea stărilor de nelinişte, cu inducerea unei stări de calm şi relaxare.

Lavanda (Lavandula augustifolia officinalis/ vera) face parte din familia Lamiaceae (sau Labiatae), provine din zona mediteraneeană, find cultivată îndeosebi în Bulgaria şi Franţa. Uleiul se obţine prin distilarea cu aburi a florilor şi conţine acetat de linalil, linalol, acetat de lavandulil, are o aromă dulce, florală, de iarbă, culoare incoloră până la galben pal.

\section{MATERIAL ŞI METODĂ}

Au fost luaţi în studiu 20 de pacienţi, 10 bărbaţi şi 10 femei, având vârste cuprinse între 20 şi 40 ani.

Aceştia au fost evaluaţi, în ceea ce priveşte semnele anxietăţii, în două vizite la cabinetul dentar, într-o şedinţă de tratament obişnuită, fără utilizarea aromaterapiei, comparativ cu o şedinţă în care s-a utilizat aromaterapia în ambientul cabinetului.

Pacienţii luaţi în studiu au fost selecţionaţi astfel încât să aibă un status emoţional echilibrat, să nu prezinte alergii la componentele uleiului esenţial. A fost obţinut consimţământul informat al acestora.

Prima dintre vizitele la cabinetul dentar s-a desfăşurat normal, în cea de-a doua vizită a fost utilizat vaporizator electric de cameră, care difuzează ulei esenţial de lavandă (Fig. 2).

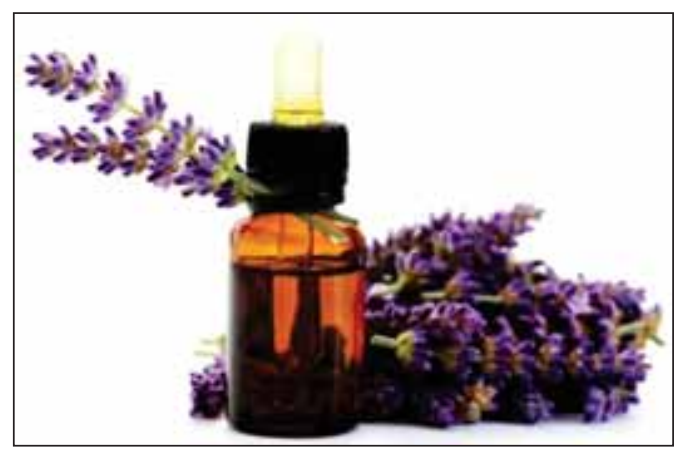

FIGURA 2. Lavanda

https://www.thriftyfun.com/Uses-for-Lavender-Essential-Oil-1.html

În fiecare dintre vizitele la cabinetul dentar, pacienţii au avut de completat chestionarul de autoevaluare, fiind considerat un timp de 10 minute ca fiind suficient.

Pentru evaluarea anxietăţii, au fost concepute diverse teste, pentru studiul de faţă utilizându-se testul S.T.A.I., care constă într-un chestionar cu două scale:

- Scală ce evaluează starea de anxietate la momentul respectiv, de aceea este considerată anxietate de stare (A-stare).

- Scală ce evaluează starea generală de anxietate, fiind definită ca anxietate trăsătură (Atrăsătură).

Fiecare dintre cele două scale cuprinde 20 de întrebări specifice la care pacientul trebuie să răspundă, existând un chestionar pentru adulţi şi unul pentru copii.

Vom utiliza chestionarul pentru adulţi specific A-stare, care evaluează starea pacientului în momentul vizitei la cabinetul dentar.

Chestionarul de autoevaluare S.T.A.I. A-stare cuprinde 20 de întrebări care descriu anumite stări sufleteşti la un moment dat (Tabelul 1).

Itemii sunt evaluaţi cu scoruri de la 1-4 astfel:

- Deloc - 1

- Puţin - 2

- Destul - 3

- Foarte mult -4

Pentru anumiţi itemi, cotarea se face invers: 1, 2, 5, 8, 10, 11, 15, 16, 19, 20. 
TABELUL 1. Chestionar STAI

\begin{tabular}{|c|l|c|c|c|c|}
\hline $\begin{array}{c}\text { Nr. } \\
\text { crt. }\end{array}$ & Întrebare & Deloc & Puțin & Destul & $\begin{array}{c}\text { Foarte } \\
\text { mult }\end{array}$ \\
\hline 1 & Mă simt calm(ă) & 4 & 3 & 2 & 1 \\
\hline 2 & Mă simt liniștit(ă) & 4 & 3 & 2 & 1 \\
\hline 3 & Sunt încordat(ă) & 1 & 2 & 3 & 4 \\
\hline 4 & Imi pare rău de ceva & 1 & 2 & 3 & 4 \\
\hline 5 & Mă simt în apele mele & 4 & 3 & 2 & 1 \\
\hline 6 & Sunt trist & 1 & 2 & 3 & 4 \\
\hline 7 & $\begin{array}{l}\text { Mă îngrijorează niște } \\
\text { neplăceri posibile }\end{array}$ & 1 & 2 & 3 & 4 \\
\hline 8 & Mă simt odihnit(ă) & 4 & 3 & 2 & 1 \\
\hline 9 & Mă simt neliniștit(ă) & 1 & 2 & 3 & 4 \\
\hline 10 & Mă simt bine & 4 & 3 & 2 & 1 \\
\hline 11 & $\begin{array}{l}\text { Am încredere în puterile } \\
\text { mele }\end{array}$ & 4 & 3 & 2 & 1 \\
\hline 12 & Mă simt nervos(nervoasă) & 1 & 2 & 3 & 4 \\
\hline 13 & Sunt speriat(ă) & 1 & 2 & 3 & 4 \\
\hline 14 & Mă simt iritat(ă) & 1 & 2 & 3 & 4 \\
\hline 15 & Mă simt relaxat(ă) & 4 & 3 & 2 & 1 \\
\hline 16 & Mă simt mulțumit(ă) & 4 & 3 & 2 & 1 \\
\hline 17 & Sunt îngrijorat(ă) & 1 & 2 & 3 & 4 \\
\hline 18 & $\begin{array}{l}\text { Mă simt agitat și scos } \\
\text { din fire }\end{array}$ & 1 & 2 & 3 & 4 \\
\hline 19 & Mă simt vesel(ă) & 4 & 3 & 2 & 1 \\
\hline 20 & Mă simt bine dispus(ă) & 4 & 3 & 2 & 1 \\
\hline
\end{tabular}

Nivelul scorului indică anxietate de stare la valori între 20 şi 80, considerând valorile maxime ca fiind asociate cu o anxietate severă. În funcţie de nivelul scorului, se poate aprecia şi nivelul anxietăţii.

\section{REZULTATE ŞI DISCUŢII}

Pacienţii luaţi în studiu au avut vârste tinere şi un nivel ridicat de educaţie, întrucât s-a constatat că persoanele cu un nivel social şi educaţional ridicat sunt receptivi la astfel de terapii alternative şi, de asemenea, persoanele tinere (13).

În urma completării chestionarelor, au fost calculate scorurile, rezultatele obţinute au fost: media obţinută pentru scala A-stare în mod obişnuit, fără utilizarea aromaterapiei, a fost de 67,3, valoarea medie a scorului de anxietate obţinută în momentul utilizării aromaterapiei în ambientul cabinetului cu ulei esenţial de lavandă a fost de 35,8 (Fig. 3).

$\mathrm{Nu}$ au fost constatate corelaţii între valorile obţinute şi vârsta pacienţilor, ceea ce semnifică faptul că nu există variaţii ale stării de anxietate legate de vârsta pacientului.
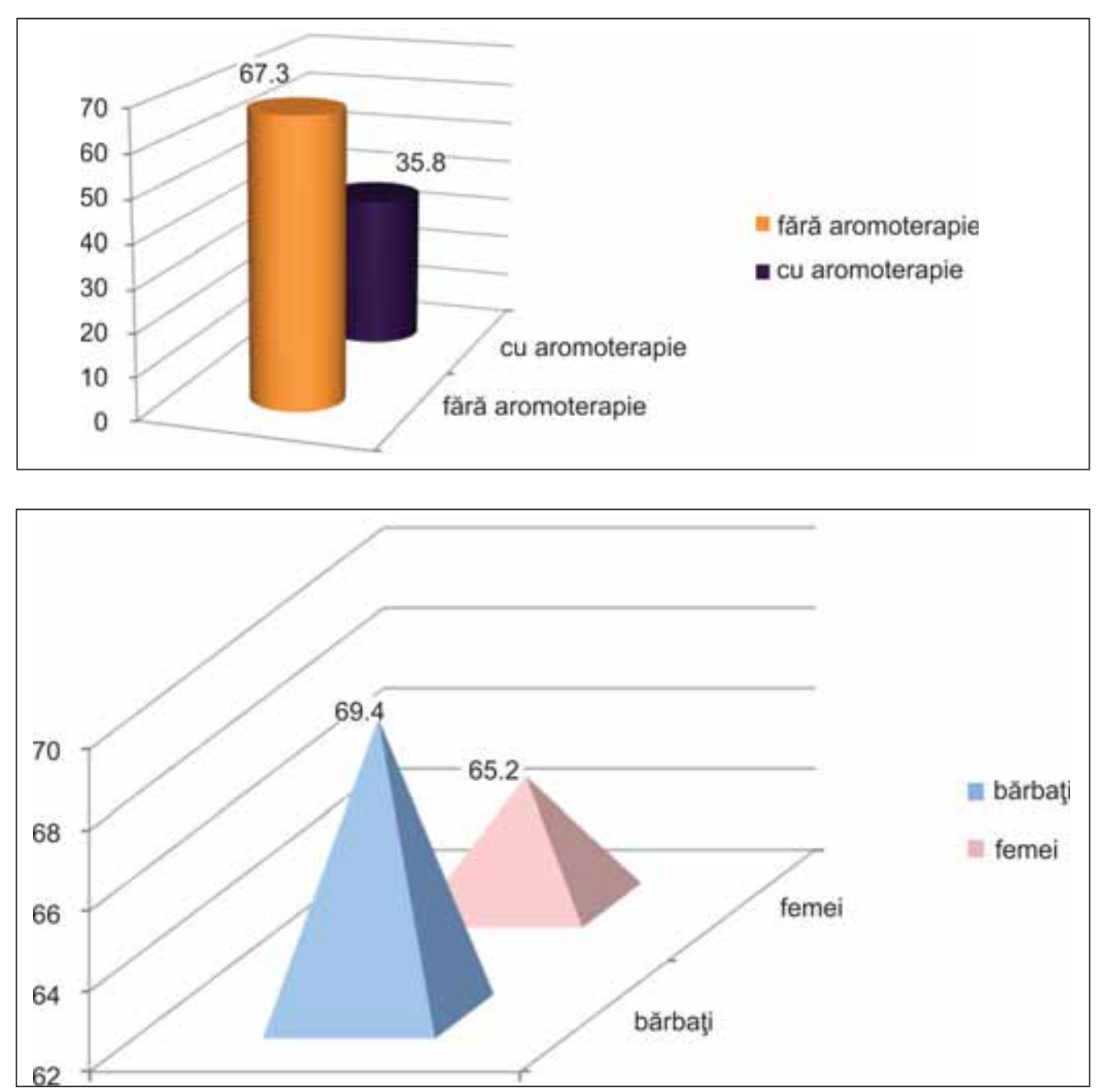

FIGURA 3. Valoarea medie STAl cu şi fara utilizarea aromaterapiei
FIGURA 4. Valori ale anxietății fără utilizarea aromaterapiei 


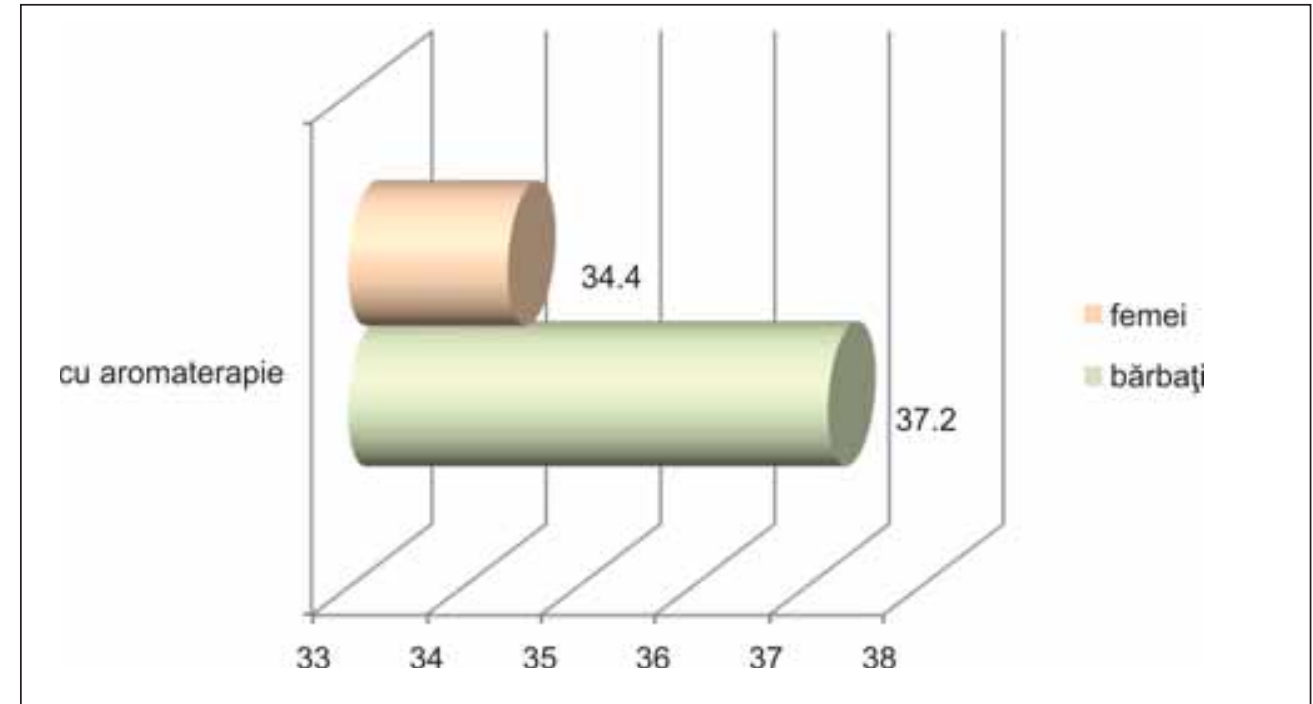

FIGURA 5. Valorile anxietății când s-a utilizat aromaterapia
Valoarea medie a scorului de anxietate a fost în prima şedinţă 69,4 pentru bărbaţi, iar pentru femei 65,2 (Fig. 4).

Valorile medii obţinute pentru pacienţii bărbaţi au fost uşor mai mari decât cele obţinute în cazul femeilor, ceea ce indică o stare anxioasă mai accentuată în cazul bărbaţilor.

În cea de-a doua şedinţă, valorile obţinute au fost de 37,2 pentru bărbaţi şi 34,4 pentru femei. Se poate observa din nou o uşoară diferenţă în funcţie de sex, cu valori mai mari la pacienţii bărbaţi faţă de femei (Fig. 5).

Toet A. et al., în 2010, şi Marchand S., Arsenault P., în 2002, în studiile lor asupra efectului aromaterapiei, au obţinut o reducere semnificativă a scorului în cazul femeilor, comparativ cu bărbaţii, după folosirea aromaterapiei.

Se observă o reducere semnificativă a valorii medii a scorului de anxietate în momentul utilizării aromaterapiei cu lavandă, ceea ce semnifică un rol deosebit de important al acestei terapii holistice (Tabelul 2).

Tabelul 2. Scorul obținut

\begin{tabular}{|l|c|c|}
\hline Scor & Fără aromaterapie & Cu aromaterapie \\
\hline General & 67,3 & 35,8 \\
\hline Bărbați & 69,4 & 37,2 \\
\hline Femei & 65,2 & 34,4 \\
\hline
\end{tabular}

Există diferenţe semnificative de scor pentru valorile obţinute înainte şi după utilizarea aromaterapiei, atât în cazul bărbaţilor, cât şi în cazul femeilor $(\mathrm{p}<0,005)$.
Inhalarea mirosului uleiului esenţial de lavandă este eficientă în reducerea nivelului anxietăţii moderate şi a formei anxietăţii de stare, nu şi asupra anxietăţii trăsătură.

Marilú Roxana Soto-Vásquez şi Paúl Alan Arkin Alvarado-García, în studiul efectuat în 2017 despre reducerea anxietăţii prin utilizarea aromaterapiei, au obţinut o reducere a valorilor scorului de anxietate pentru toate grupele de pacienţi luate în considerare (6).

Studiile efectuate arată că efectul anxiolitic al uleiurilor esenţiale se datorează componentei linalool, care induce asupra sistemului nervos central efecte de sedare, hipnoză şi anxiolitice (14-16).

Sudha Jimson subliniază în articolul review din 2016 rolul acestei terapii holistice, aromaterapia, în combaterea sau reducerea stării anxioase provocate de vizitele la cabinetul dentar. Este cunoscut faptul că sala de aşteptare poate fi un loc care provoacă o stare de nelinişte, teamă şi chiar declanşează stări de anxietate în cabinetul de medicină dentară (17).

Zabirunnisa et al., în 2014, au demonstrat că pacienţii expuşi la mirosul de ulei esenţial de lavandă au nivele scăzute de anxietate, ceea ce încurajează la utilizarea aromaterapiei şi în practica stomatologică (18).

Mirosul este considerat cel mai important dintre simţurile corpului uman, cu influenţe asupra corpului, dar şi la nivel mental (20). Aromaterapia prin inhalare funcţionează prin influenţa asupra simţului mirosului a diferitelor arome folosite, cu efect asupra emoţiilor, sentimentelor (21).

Receptorii olfactivi sunt foarte sensibili şi pot fi stimulaţi chiar de mirosuri foarte fine şi subtile 
(22). Uleiul esenţial de lavandă şi bergamotă are efecte de relaxare şi antidepresive, după cum demonstrează studii din $2003(25,26)$.

Cercetările ştiinţifice au demonstrat efectul aromaterapiei ca intervenţie holistică cu efect de relaxare (27). Aromaterapia reduce nivelul anxietăţii şi stresul, îmbunătăţind calitatea somnului pentru pacienţi cu diverse afecţiuni, cancer, hemodializă, colonoscopie $(25,28-31)$.

Inhalarea parfumului uleiurilor esenţiale este o tehnică folosită pentru reducerea durerii, a anxietăţii şi a depresiei şi îmbunătăţirea semnelor vitale (32).

Ezgi Karadag et al. au obţinut în studiul lor din 2015 o reducere semnificativă a valorilor anxietăţii pentru pacienţii din grupul de studiu comparativ cu grupul control în urma folosirii aromaterapiei (33).

Numeroase studii au obţinut o reducere a scorului de stres, anxietate şi depresie în urma aplicării unor programe de aromaterapie (34).

De asemenea, Lehrner J et al., în 2005, au demonstrat în studiul lor că uleiurile esenţiale folosite ca odorizant ambiental au efect reducerea anxietăţii şi îmbunătăţirea dispoziţiei în cabinetul dentar (12).

Jellinet J.S. concluzionează într-o lucrare din 1994 necesitatea studierii efectului mixturii de arome odorizante, ca şi a mirosurilor unice, şi, de asemenea, compararea efectului aromelor naturale $\mathrm{cu}$ al celor sintetice (35).

\section{CONCLUZII}

Aromaterapia este o terapie complementară ce poate fi folosită cu succes în practica stomatologică pentru a îmbunătăţi condiţiile de lucru, prin crearea unui ambient mai plăcut şi mai puţin stresant pentru pacienţi. Astfel, pacienţii vor avea o atitudine mai relaxată, reducându-se încordarea, tensiunea şi emoţiile negative.

\section{NOTĂ}

Toţi autorii au participat în mod egal la realizarea acestui articol.

Conflict of interest: none declared Financial support: none declared

\section{BIBLIOGRAFIE}

1. Chatterjee M., Verma R., Lakshmi V. Anxiolytic effects of Plumeria rubra var. acutifolia (Poiret) L. flower extracts in the elevated plus-maze model of anxiety in mice. Asian $\mathrm{J}$ Psychiatr. 2013; 6:113-118.

2. Moore R., Brødsgaard I. Differential diagnosis of odontophobic patients using the DSM-IV. Eur J Oral Sci. 1995; 103:121-126.

3. Gross P.R. Is pain sensitivity associated with dental avoidance? Behav Res Ther. 1992; 30:7-13.

4. Toet A., Smeets M.A., van Dijk E., Dijkstra D., van den Reijen L. Effects of Pleasant Ambient Fragrances on Dental Fear: Comparing Apples and Oranges. Chemosens Percept. 2010; 3:182-89.

5. Marchand S., Arsenault P. Odors modulate pain perception: A gender-specific effect. Physiol Behav. 2002; 76:251-6.

6. Marilú Roxana Soto-Vásquez, Paúl Alan Arkin AlvaradoGarcía. Aromatherapy with two essential oils from Satureja genre and mindfulness meditation to reduce anxiety in humans; J Tradit Complement Med. 2017 Jan; 7(1): 121-125.

7. Ava Elizabeth Carter, Geoff Carter, Mark Boschen, Emad Al Shwaimi, Roy George. Pathways of fear and anxiety in dentistry: A review, World J Clin Cases. 2014 Nov 16; 2(11): 642-653.

8. Spielberger C. Manual for the State-Trait Anxiety Inventory (rev. ed.). Palo Alto (CA): Consulting Psychologists Press; 1983.

9. Spielberger CD., Reheiser E.C., Ritterband L.M., Sydeman S.J., Unger K.K. (1995) Assessment of Emotional States and Personality Traits: Measuring Psychological Vital Signs. In Butcher, J.N. (Ed.) Clinical Personality Assessment: Practical Approaches. New York: Oxford University Press, 1995
10. Valerie Ann Worwood. The complete book of essential oils and aromatherapy, New World Library, 1991

11. Cassandra Santantonio de Lyra, Larissa Sayuri Nakai, Amélia Pasqual Marques. Eficácia da aromaterapia na redução de níveis de estresse e ansiedade em alunos de graduação da área da saúde: estudo preliminar Fisioter. Pesqui. vol.17 no.1 São Paulo Jan./Mar. 2010

12. Lehrner J., Marwinski G., Lehr S., Johren P., Deecke L. Ambient odors of orange and lavender reduce anxiety and improve mood in a dental office. Physiol Behav. 2005 Sep 15; 86(1-2):92-5.

13. Hawk C., Ndetan H., Evans Jr. M.W. Potential role of complementary and alternative health care providers in chronic disease prevention and health promotion: an analysis of National Health Interview Survey data. Prev Med. 2012; 54:18-22

14. Linck V.M., Da Silva A.L., Figueiró M. Effects of inhaled Linalool in anxiety, social interaction and aggressive behavior in mice. Phytomedicine. 2010; 17:679-683

15. Guzman-Gutierrez S.L., Gómez-Cansino R., GarcíaZebadúa J.C., Jimenéz-Peréz N.C., Reyes-Chilpa R. Antidepressant activity of Litsea glaucescens essential oil: identification of b-pinene and linalool as active principles. J Ethnopharmacol. 2012; 143:673-679

16. Cheng B.H., Sheen L.Y., Chang S.T. Evaluation of anxiolytic potency of essential oil and S-(p)-linalool from Cinnamomum osmophloeum ct. linalool leaves in mice. J Tradit Complement Med. 2015; 5:27-34.

17. Sudha Jimson, G.N. Devi, L. Malathi, Leena S. Sankari. Aromatherapy in Dentistry - A Review Article in Biomedical and Pharmacology Journal 9(2):827-828, August 2016 
18. M. Zabirunnisa, Jayaprakash S. Gadagi, Praveen Gadde, Nagamalleshwari Myla, Jyothirmai Koneru, Chandrasekhar Thatimatla. Dental patient anxiety: Possible deal with Lavender fragrance, J Res Pharm Pract. 2014 Jul-Sep; 3(3): 100-103.

19. Jacqueline Russo. Diffusing Dental Anxiety with Aromatherapy, RN, DDS, March 8, 2017

20. Arshia Rashid Baig, Sadashiv Daokar, Syed Navid Ali. Aromatic Dentistry, IOSR Journal of Dental and Medical Sciences (IOSR-JDMS) e-ISSN: 2279-0853, p-ISSN: 2279-0861.Volume 16, Issue 5 Ver. IV (May. 2017), PP 57-60

21. Jafarzadeh M., Arman S., Pour F.F. Effect of aromatherapy with orange essential oil on salivary cortisol and pulse rate in children during dental treatment: A randomized controlled clinical trial. Adv Biomed Res 2013; 2: 10

22. Hummel T., Olgun S., Gerber J., Huchel U., Frasnelli J. 2013, Brain responses to odor mixtures subthreshold components, Front Psychol., 24;4: 786,

23. http://tylerwellnesscenter.com/2016/10/essential-oils-boosthealth/

24. https://www.thriftyfun.com/Uses-for-Lavender-Essential-Oil-1. html

25. Battaglia S. The Complete Guide to Aromatherapy. Brisbane, Australia: The International Center of Holistic Aromatherapy; 2003.

26. Buckle J. Clinical Aromatherapy: Essential Oils in Practice, Churchill Livingstone, New York, NY, USA, 2nd edition, 2003.

27. Choi O.B., Kim O.K. Aromatherapy, Seoul, Republic of Korea: Fabre Eduterial, 2001

28. Hwang J.H. The effects of the inhalation method using essential oils on blood pressure and stress responses of clients with essential hypertension. Taehan Kanho Hakhoe Chi. 2006; 36(7):1123-1134.

29. Lee E., Kim K.S. The effects of aroma hand massage on anxiety and sleep in cancer patients during hospitalization. Perspective in Nursing Science. 2011; 8(1):42-53.

30. Kim O.J., Kim K.H., Park K.S. The effect of aroma inhalation on stress, anxiety and sleep pattern in patients with hemodialysis. Journal of the Korean Clinical Nursing Research. 2007; 13(2):99-111.

31. Lee Y.M., Ahn H.Y. Effect of the aromatherapy on anxiety and discomfort in patients having colonoscopy. Journal of Korean Academy of Fundamentals of Nursing. 2010; 17(4):539-547.

32. Seifi Z., Beikmoradi A., Oshvandi K., Poorolajal J., Araghchian M., Safiaryan R. (2014). The effect of lavender essential oil on anxiety level in patients undergoing coronary artery bypass graft surgery: a double-blinded randomized clinical trial. Iranian Journal of Nursing and Midwifery Research; 19: 574- 580

33. Ezgi Karadag, Dilek Ozden, Sevgin Samancioglu, Ercan Bakir. Effects of aromatherapy on sleep quality and anxiety of patients, Nursing in Critical Care. July 2015

34. Price S., Oram S.A. Care of the elderly, in Aromatherapy for Health Professionals, pp. 261-272, Churchill Livingstone/ Elsevier, Edinburgh, UK, 4th edition, 2012. View at Google Scholar

35. Jellinet J.S. Aromachology: A status review, Perfum Flavor 1994, 19: 25-49 